\title{
Calcitonin gene-related peptide and pain: a systematic review
}

\author{
Wendy Sophie Schou', Sait Ashina², Faisal Mohammad Amin', Peter J. Goadsby ${ }^{3}$ and Messoud Ashina ${ }^{1 *}$
}

\begin{abstract}
Background: Calcitonin gene-related peptide (CGRP) is widely distributed in nociceptive pathways in human peripheral and central nervous system and its receptors are also expressed in pain pathways. CGRP is involved in migraine pathophysiology but its role in non-headache pain has not been clarified.

Methods: We performed a systematic literature search on PubMed, Embase and ClinicalTrials.gov for articles on CGRP and non-headache pain covering human studies including experimental studies and randomized clinical trials.

Results: The literature search identified 375 citations of which 50 contained relevant original data. An association between measured CGRP levels and somatic, visceral, neuropathic and inflammatory pain was found. In 13 out of 20 studies in somatic pain conditions, CGRP levels had a positive correlation with pain. Increased CGRP levels were reported in plasma, synovial and cerebrospinal fluid in subjects with musculoskeletal pain. A randomized clinical trial on monoclonal antibody, which selectively binds to and inhibits the activity of CGRP (galcanezumab) in patients with osteoarthritis knee pain, failed to demonstrate improvement of pain compared with placebo. No studies to date have investigated the efficacy of monoclonal antibodies against CGRP receptor in non-headache pain conditions.

Conclusion: The present review revealed the association between measured CGRP levels and somatic, visceral, neuropathic and inflammatory pain. These data suggest that CGRP may act as a neuromodulator in non-headache pain conditions. However, more studies are needed to fully understand the role of CGRP in nociceptive processing and therapy of chronic pain.
\end{abstract}

\section{Background}

The mechanism of nociception is complex involving the detection of a noxious event by nociceptors, and signal processing in the peripheral and central nervous system (CNS). Recent studies have identified specific substances and receptors with potential roles in nociception that provide therapeutic targets, including substance P, CGRP, glutamate, serotonin, TrkA receptor, vanilloid receptor and NMDA receptor $[1,2]$. Chronic pain resulting from disease or injury is a major public health problem and a common complaint in general population with a lifetime prevalence ranging from 12 to $30 \%$ [3] and an enormous impact and burden on society and individuals [4]. Despite tremendous scientific effort over the past years, current pain management treatment remains suboptimal [5]. There is an unmet

\footnotetext{
* Correspondence: ashina@dadlnet.dk

'Danish Headache Center, Department of Neurology, Rigshospitalet Glostrup,

University of Copenhagen, Copenhagen, Denmark

Full list of author information is available at the end of the article
}

and urgent need for new effective therapeutic options for the management of chronic pain. Migraine manifests as pain with associated sensory disturbances and is considered as a chronic condition with episodic manifestations [6]. The role of CGRP in migraine pathophysiology has gained considerable interest in recent years $[7,8]$. This led to the development of small molecule CGRP receptor antagonists for acute and preventive treatment of migraine $[9,10]$ and monoclonal antibodies against CGRP mechanisms for migraine prevention $[11,12]$.

CGRP is a 37-amino-acid neuropeptide identified in 1982 [13]. It belongs to a family of peptides including adrenomedullin, amylin and calcitonin with diverse biological functions in the periphery and in the central nervous system [14, 15]. To what extent CGRP is involved in non-headache pain conditions is not fully clarified and whether CGRP antagonism may represent a useful therapeutic approach for the treatment of chronic pain is unknown. 
The aim of this systematic review was to assess the role of CGRP in non-headache pain in humans. In addition we discussed the potential role of anti-CGRP agents in the management of chronic pain.

\section{Methods}

\section{Literature search}

We performed a systematic literature search identifying articles reporting original data on CGRP and nonheadache pain. We concluded the literature search on Pubmed Embase and ClinicalTrials.gov on May 2016. We used the following search terms: CGRP and pain. In addition, we specified our search criteria in ClinicalTrials.gov to currently available monoclonal antibodies against CGRP (LY2951742, ALD-403, PF-04427429, LBR-101/TEV-48125) or its receptor (AMG334), and CGRP receptor antagonists (BIBN4096BS, MK-0974, MK-3207, MK-1602, MK-8825, BMS-694153, BMS927711, BMS-742413, BI 44370 TA) [16].

Only human studies published in English language were included. Review papers editorials and other articles without original data were excluded. We also considered articles from the reference list of studies that were found to be relevant as well as literature that was known to be relevant by the authors.

\section{Data extraction}

The authors (WSS) examined the abstracts found in the literature search. Whenever the title or abstract suggested that relevant data could be part of the publication the entire article was read and discussed with the other co-authors. Studies in which patients had unclear pain history or articles without relevant data on CGRP were not included in the review.

\section{Results}

Our Pubmed Embase and ClinicalTrials search strategy identified 375 hits of which 50 studies were included in the final review (Fig. 1). After excluding 110 as duplicates, another 118 hits were excluded because these were abstracts, reviews, animal, migraine, headache studies, and incomplete studies. Subsequently, we excluded 97 studies that did not describe pain history of the patients, had no relevant data on CGRP, or had unclear methodology. In total, 50 studies were included in the final review (Fig. 1). The identified studies were further divided into five categories: 1) somatic pain, 2) visceral pain, 3) inflammatory pain, 4) neuropathic pain, and 5) clinical trials (Fig. 2).

\section{Somatic pain}

We found a total of 20 studies on the role of CGRP in somatic pain (Table 1). Using different methodological approaches and CGRP sample sources 13 studies showed higher levels of CGRP compared to controls. Eight studies directly tested for a possible correlation between pain intensity and CGRP levels. In chronic knee pain due to osteoarthrosis elevated CGRP levels were detected in serum and synovial fluid in patients compared with controls. Serum CGRP levels were positively correlated with pain intensity [17]. Chronic low back patients due to osteoarthrosis showed decreased blood CGRP levels four months after successful auricular point acupressure pain treatment compared to baseline. No decrease was found in patients who received sham treatment [18]. In addition, studies using immunofluorescence

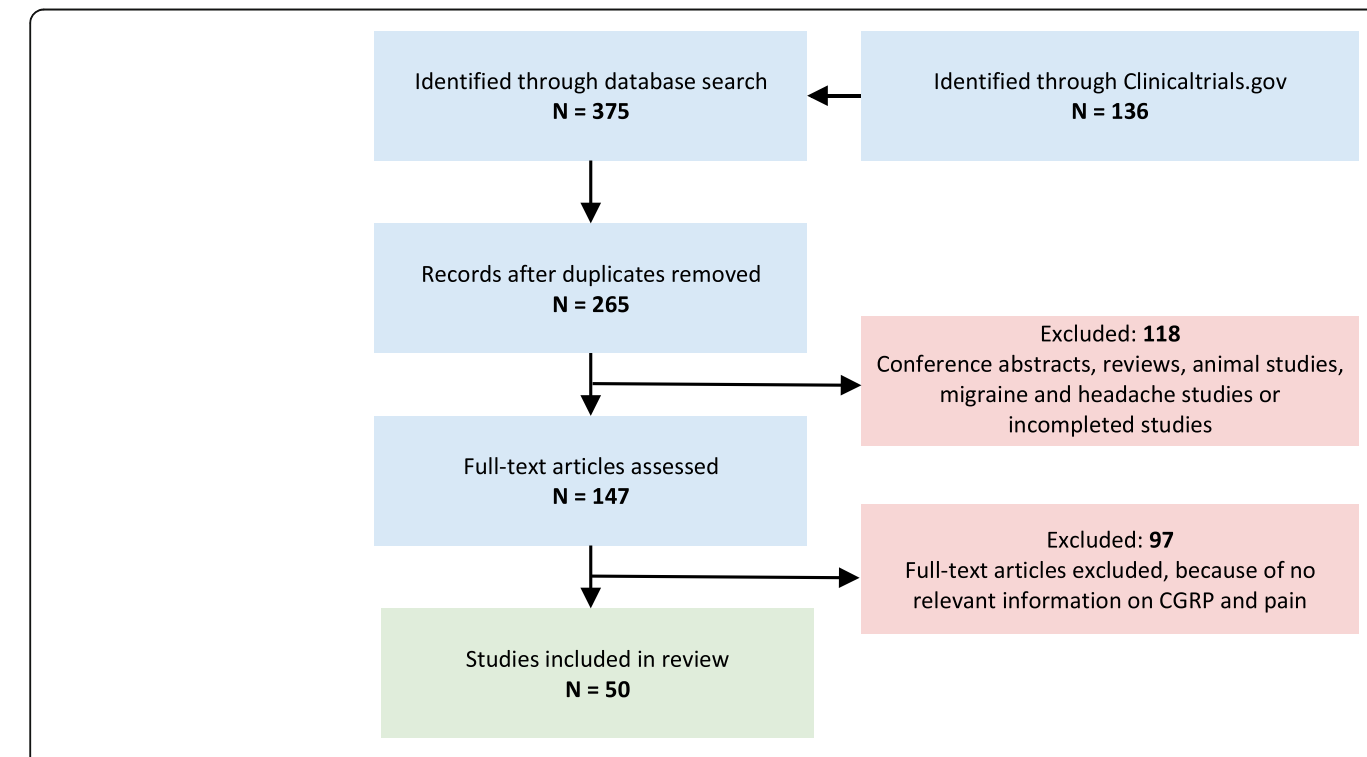

Fig. 1 Flow chart of the study 


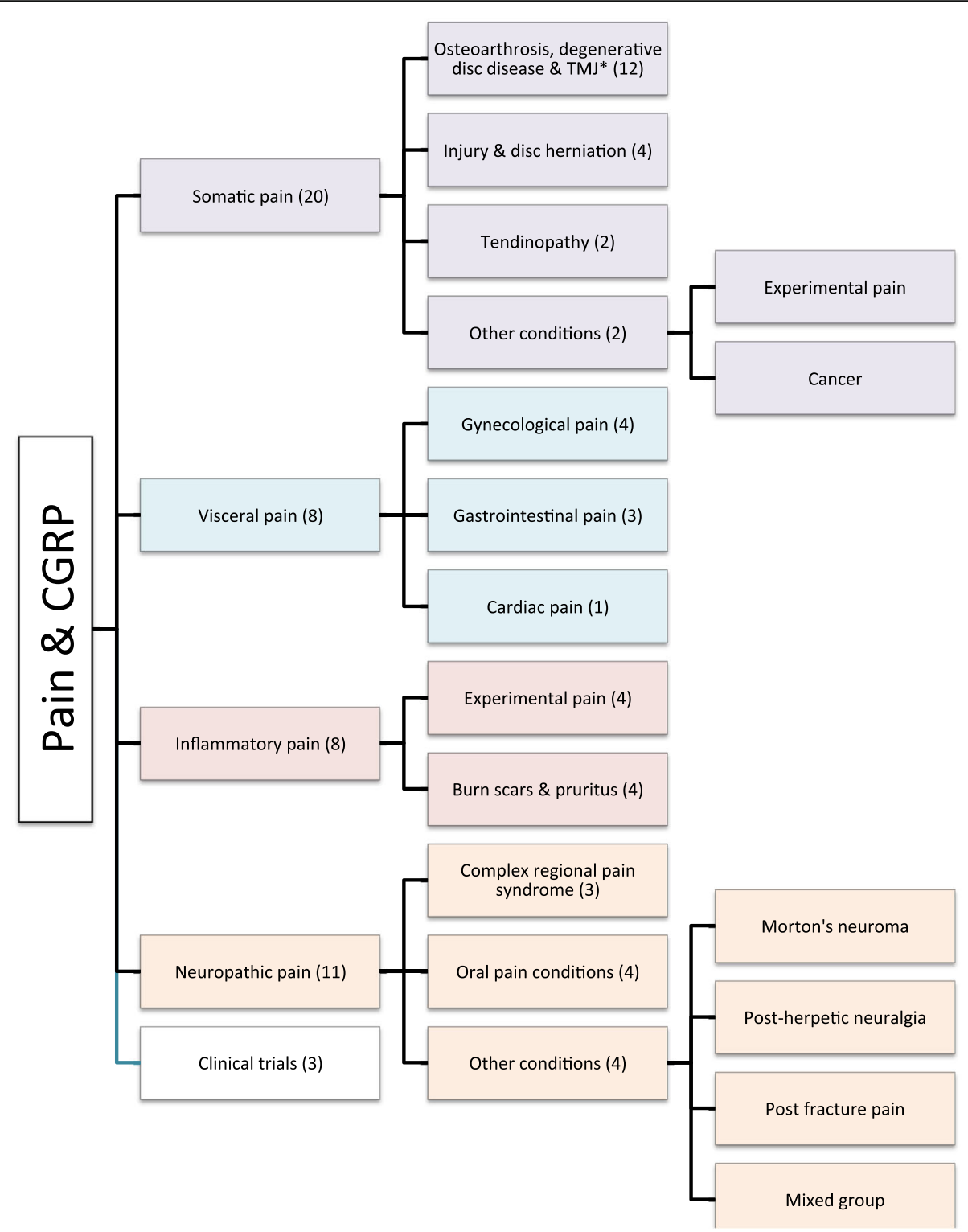

Fig. 2 Overview of the studies in non-headache pain included in each category in the present review

of skin biopsies reported decreased CGRP after acupuncture treatment of osteoarthrosis patients [19]. Immunohistochemistry analysis of synovial tissue from fossa acetabuli showed increased CGRP levels in patients compared to controls [20,21]. One study reported higher levels of CGRP in hip synovium from osteoarthritis patients compared with femoral neck patients [22]. Moreover, one study [23] revealed higher levels of CGRP in synovial tissue from temporomandibular joint (TMJ) pain patients compared with controls. This study also reported positive correlation between pain and CGRP levels [23]. Biopsies from knee joint ligaments showed no difference in CGRP nerve density between patients and non-arthrosis patients [24]. In patients with osteoarthrosis CGRP concentration in cerebrospinal fluid was decreased compared to controls [25].

In patients suffering from chronic pain due to degenerative disc disease disc biopsies showed increased CGRP compared to post-mortem control discs [26]. Biopsies from intervertebral discs in patients with low back pain contained CGRP-IR nerve fibers [27].

Patients suffering from shoulder and neck pain due to whiplash injury were found to have higher blood CGRP levels compared to controls [28]. Another study of patients with disc herniation pain reported increased blood levels of CGRP which were normalized after discectomy [29]. Blood CGRP levels were also elevated in patients with soft tissue injury (i.e. muscle or ligament pain) 


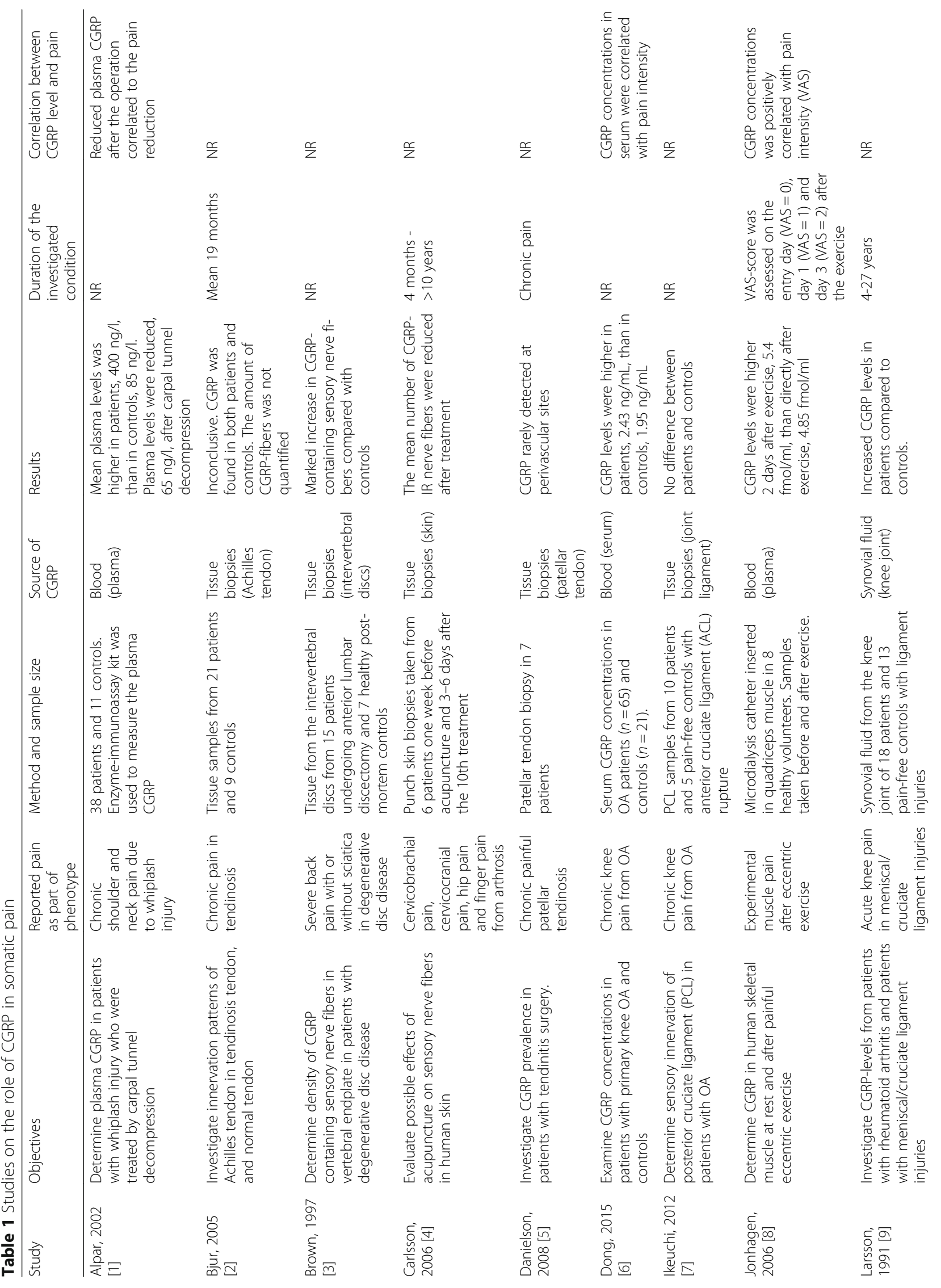




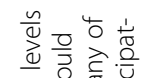

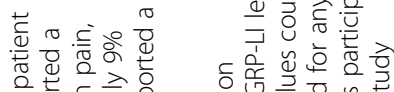

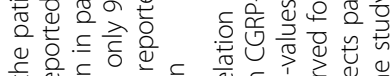

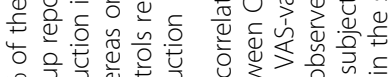

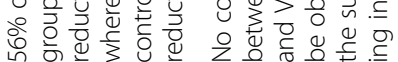

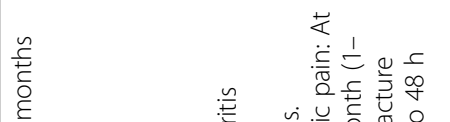

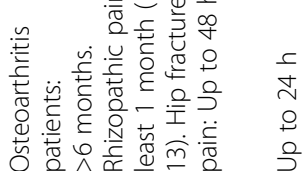

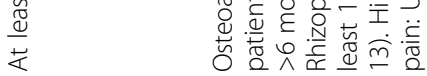

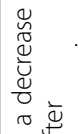

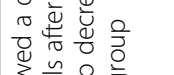

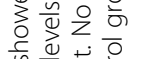

气ै वे

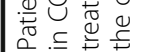

중

$\begin{array}{ll}\overline{0} & \frac{\varepsilon}{4} \\ 0 & \frac{\pi}{0} \\ 0 & \frac{\pi}{9}\end{array}$

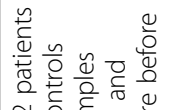

苟

m

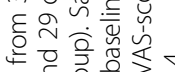

$\begin{array}{llll} & \\ 0\end{array}$

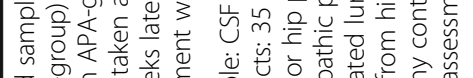

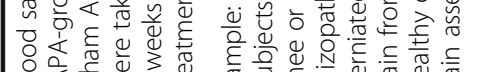

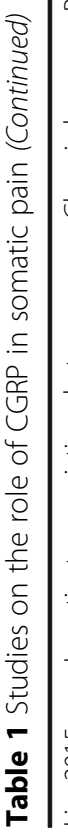

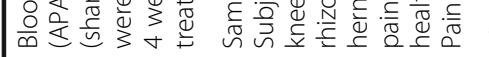

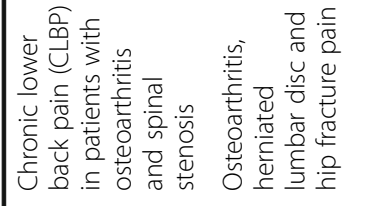

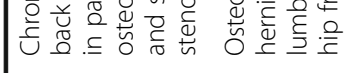

年

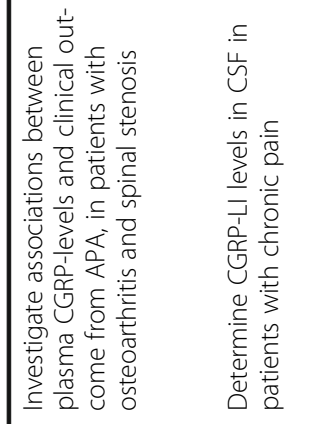

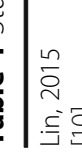

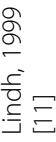

$\stackrel{\frac{c}{z}}{\frac{c}{z}}$

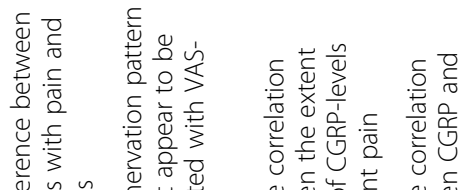

웜

है을

증흥용

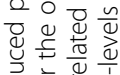

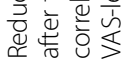

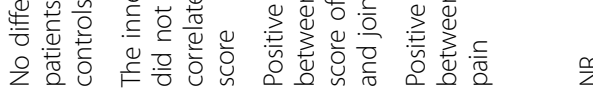

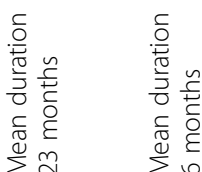<smiles>C1CC2CCB1C2</smiles>

$\stackrel{\circ}{\frac{a}{z}} \quad \stackrel{\frac{\pi}{\pi}}{\Sigma}$

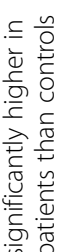

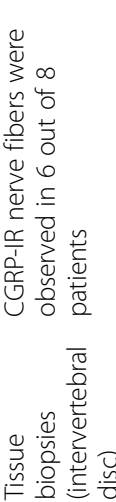

$\frac{n}{0}$

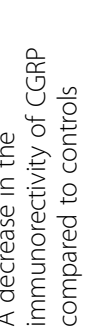

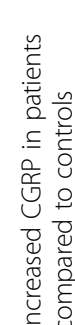

$\stackrel{\frac{a}{z}}{2}$

(a)

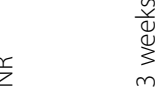

要

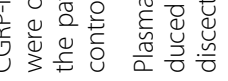

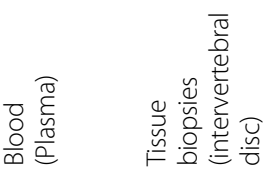

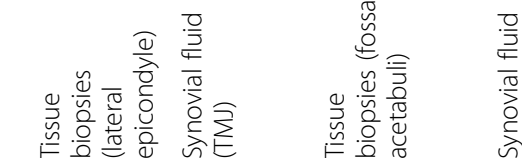

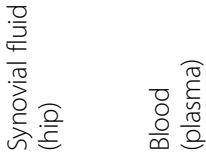

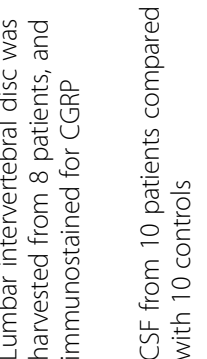

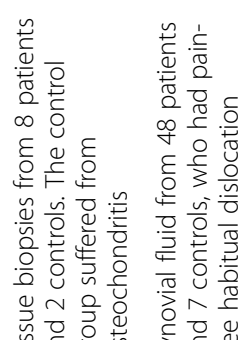

$\varpi \frac{n}{0} \stackrel{0}{0}$

总

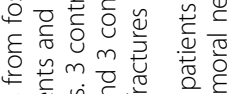

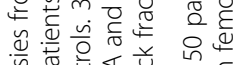

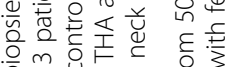

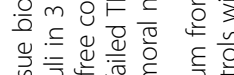

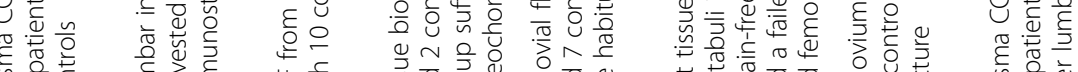

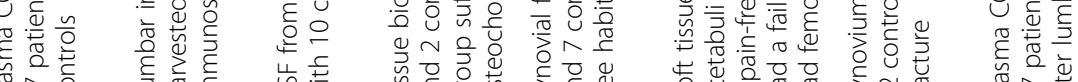

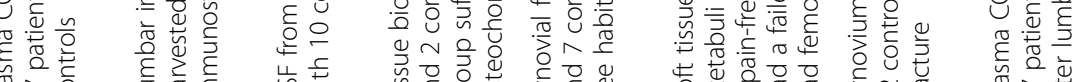

$\cong \frac{v}{\stackrel{v}{u}}$

蛋 ${ }^{m}$ हे

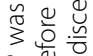

舒离离

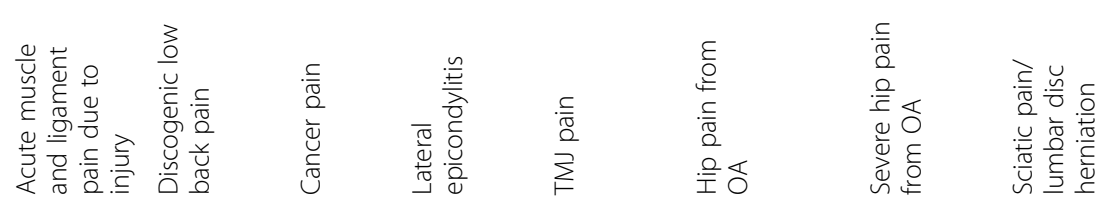

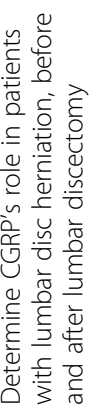

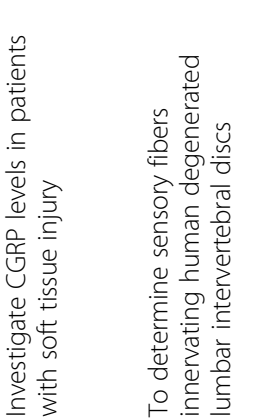

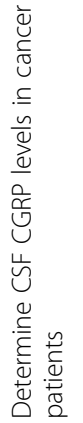

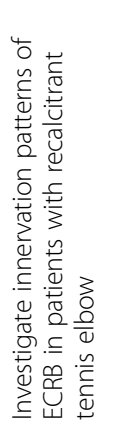

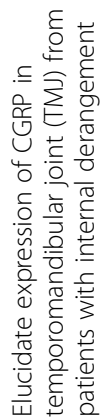

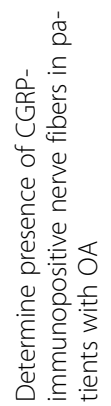

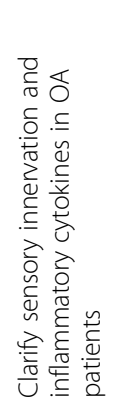

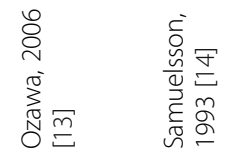

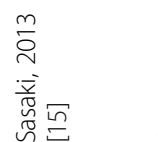

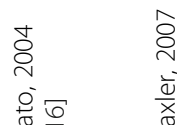

产

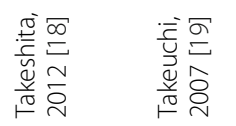




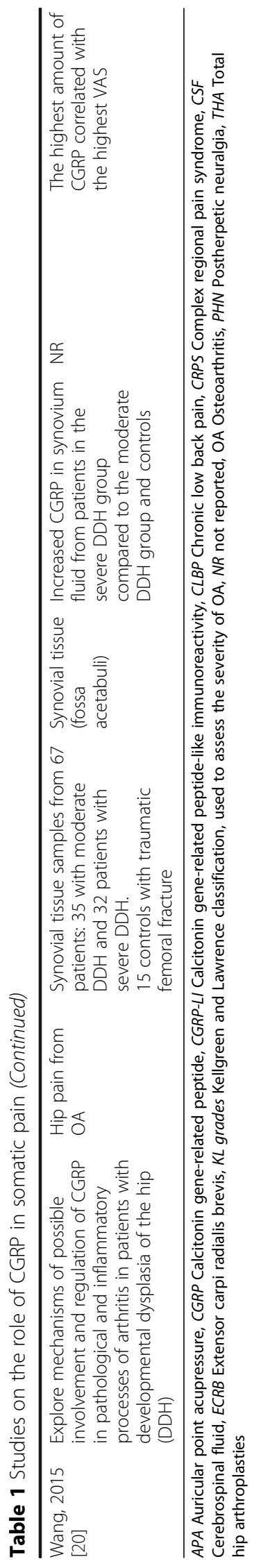


compared with controls [30]. Furthermore, one radioimmunoassay study of knee synovial fluid from patients with meniscal or ligament injury revealed higher CGRP levels compared to controls [31].

Immunohistochemistry analysis of biopsies of Achilles tendons from patients with chronic painful tendinosis showed no changes in CGRP levels in patients compared to controls [32] while another study in patients with patellar tendinosis found the presence of CGRP, but had no control group [33]. One study reported decreased CGRP in the extensor carpi radialis brevis tendon biopsy from patients with tennis elbow compared to patients with osteochondritis [34].

Samuelsson and colleagues [35] compared CGRP levels in cerebrospinal fluid from cancer patients with pain and found no difference between patients and non-pain control patients. A microdialysis study in the vastus lateralis of the quadriceps muscles before and during pain after eccentric exercise (repetitive muscle contractions while the muscle is lengthening under load) reported increased CGRP levels during pain compared with baseline [36].

\section{Visceral pain}

Eight studies examined CGRP in different types of visceral pain conditions (Table 2).

Immunofluorescence-based analysis of peritoneal fluid obtained during diagnostic laparoscopy in patients with endometriosis showed increased CGRP levels compared to peritoneal fluid from controls without endometriosis [37]. Visual analogue scale scores were registered in all patients but authors found no correlation between CGRP levels and severity of pain. Immunohistochemistry analyses of peritoneal endometriotic lesions and normal peritoneum from non-endometriotic women showed increased CGRP in affected tissue material [38]. Using the same technique, increased CGRP levels were found in endometrium and myometrium in women with, but not in those without endometriosis. Pain measurement data was not reported [39]. CGRP levels were also studied in patients with vulvodynia. Analysis of vulval vestibule tissue revealed no differences in CGRP levels between patients with vulvodynia and controls [40].

Gastric mucosal biopsies from patients with nonerosive reflux disease [41] and functional dyspepsia [42] were investigated with enzyme- and radioimmunoassay. None of the studies found differences in CGRP levels between patients and controls but a negative correlation between CGRP concentrations and pain scores was reported in the latter [42]. CGRP has also been investigated with immunohistochemistry in patients with alcohol-based painful chronic pancreatitis and increased CGRP levels in patients were reported compared with pancreatic tissue from organ donors [43].
Plasma CGRP levels were studied in patients with suspected or definite acute myocardial infarction at admission at a coronary care unit [44]. This study revealed no difference in CGRP levels between patients with and without acute myocardial infarction and no difference between patients with pain and those without pain.

\section{Inflammatory pain}

Eight studies on CGRP and inflammatory pain conditions were identified (Table 3). ELISA of dermal microdialysate from volar forearm showed elevated blood CGRP levels in ten healthy volunteers with capsaicininduced pain [45]. No CGRP release was detected via dermal microdialysate after electrical stimulation in the same area. Correlation between pain intensity or threshold and CGRP concentration was not tested [45]. In contrast another study found CGRP in the dialysate after histamine iontophoresis, but not after capsaicin application in the volar forearm [46]. One study performed immunohistochemistry of skin biopsies after intradermal capsaicin injection and reported complete loss of CGRP visualization $72 \mathrm{~h}$ after injection [47].

Using the ELISA and dermal microdialysis method in healthy volunteers CGRP release was reported after electrical stimulation upon phosphoramidon but not after captopril infusion in the volar forearm [48]. Phosphoramidon and captopril, respectively, inhibit neutral endopeptidase and angiotensin-converting hormone, which are both involved in neuropeptide degradation [49].

Immunohistochemical analysis of skin biopsies in patients with painful scars from burn showed increased CGRP compared with controls with burn scars without pain [50]. Another study reported increased CGRP in hypertrophic burn scar compared to biopsies from unburned scars. Pain intensity was higher in patients with burn scars [51]. Moreover ELISA of peripheral blood showed increased CGRP levels up to $24 \mathrm{~h}$ after burn injuries compared with healthy volunteers [52] and in patients with pruritus due to atopic dermatitis [53]. Furthermore, CGRP levels were positively correlated with the severity of pruritus [53]. Nociceptive fibers have been shown to be involved in the sensation of pruritus [54].

\section{Neuropathic pain}

We identified 11 studies in this category (Table 4). Radioimmunoassay showed higher serum CGRP levels in 19 patients with complex regional pain syndrome (CRPS) compared to controls. The difference was normalized after a 9-month pain management therapy [55]. In contrast another study found decreased serum CGRP levels in chronic CRPS patients $(n=12)$ compared with healthy controls [56]. No correlation between pain and CGRP levels was found in either study [55, 56]. Moreover, immunofluorescence analysis of skin biopsies from 


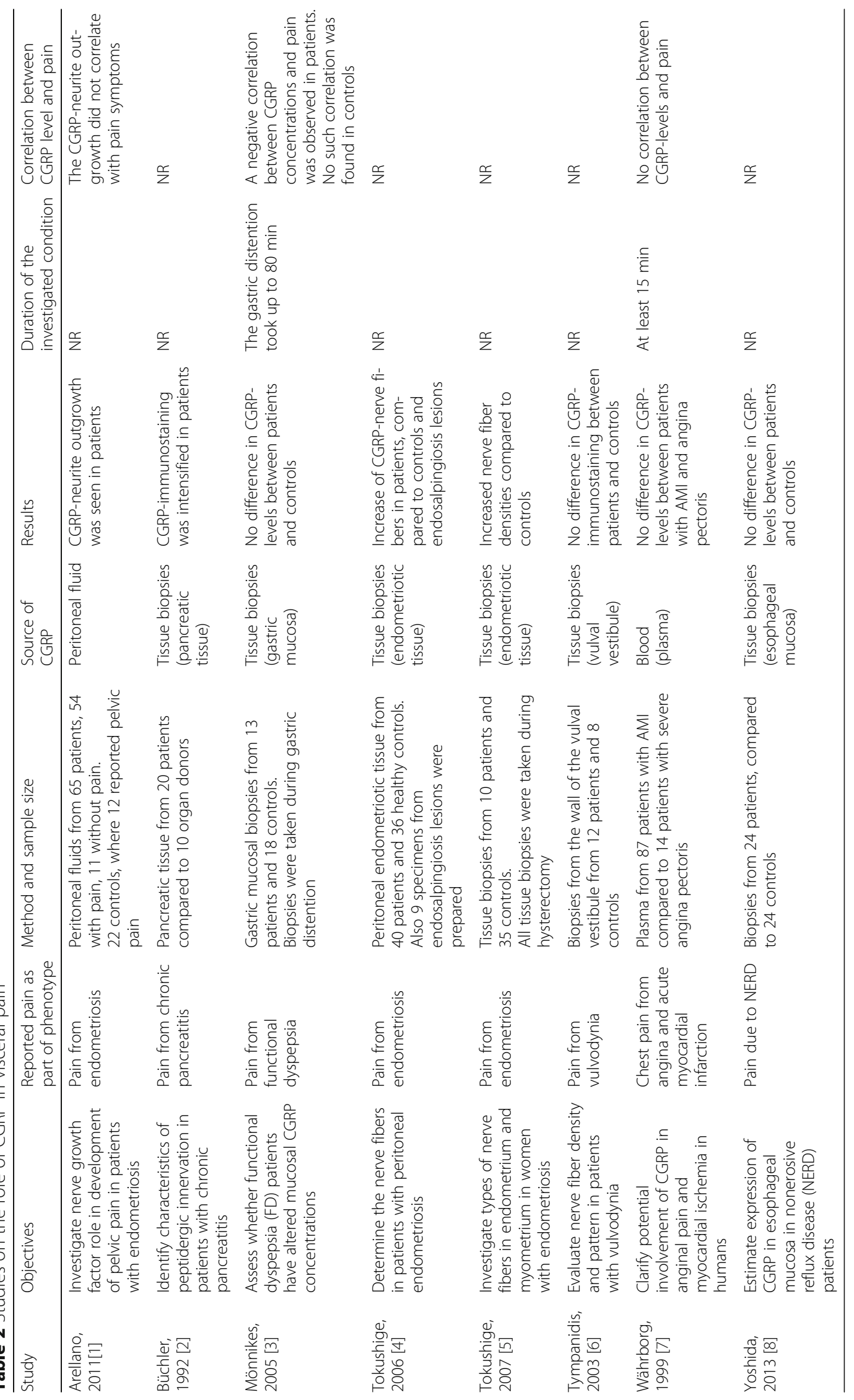




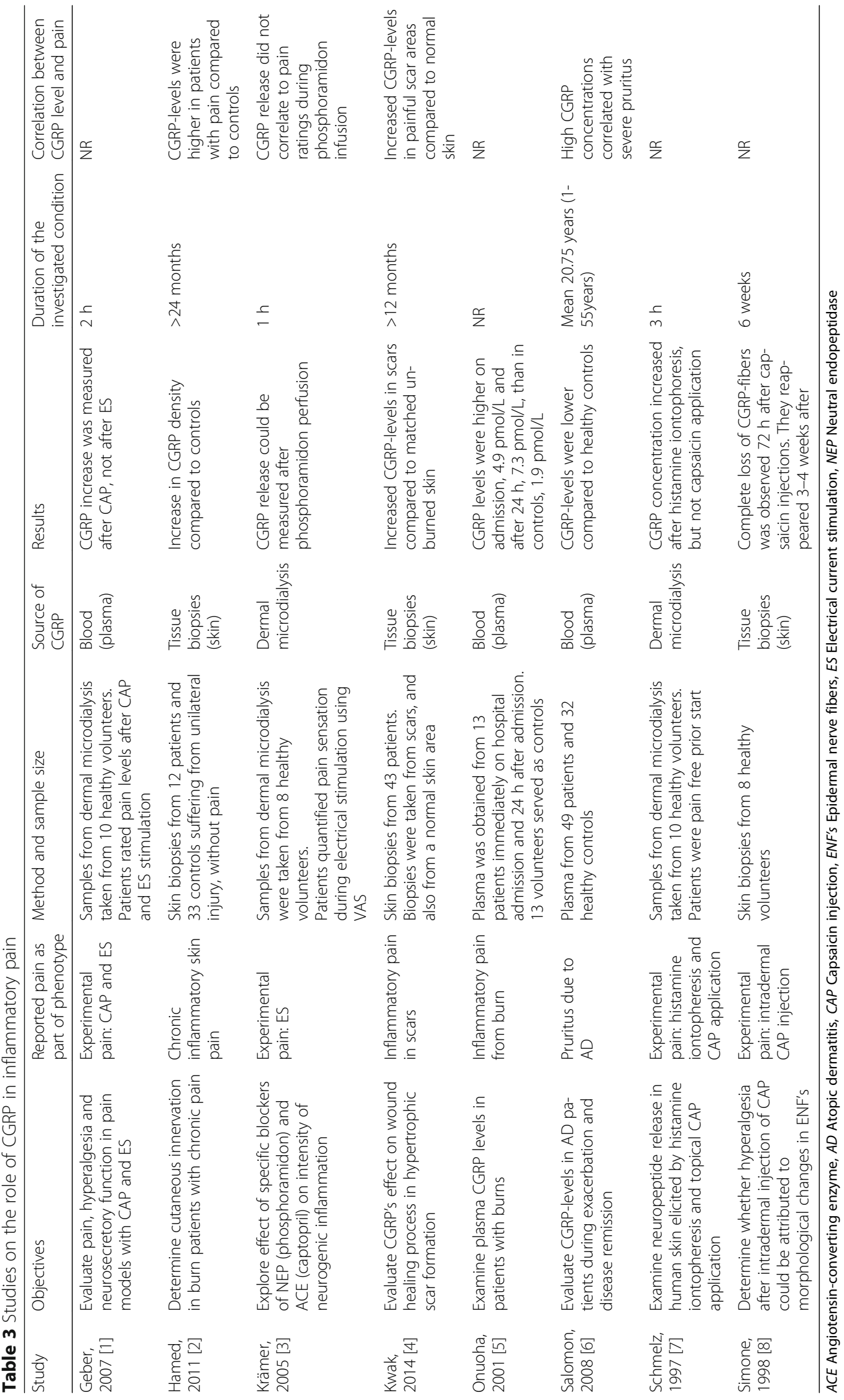




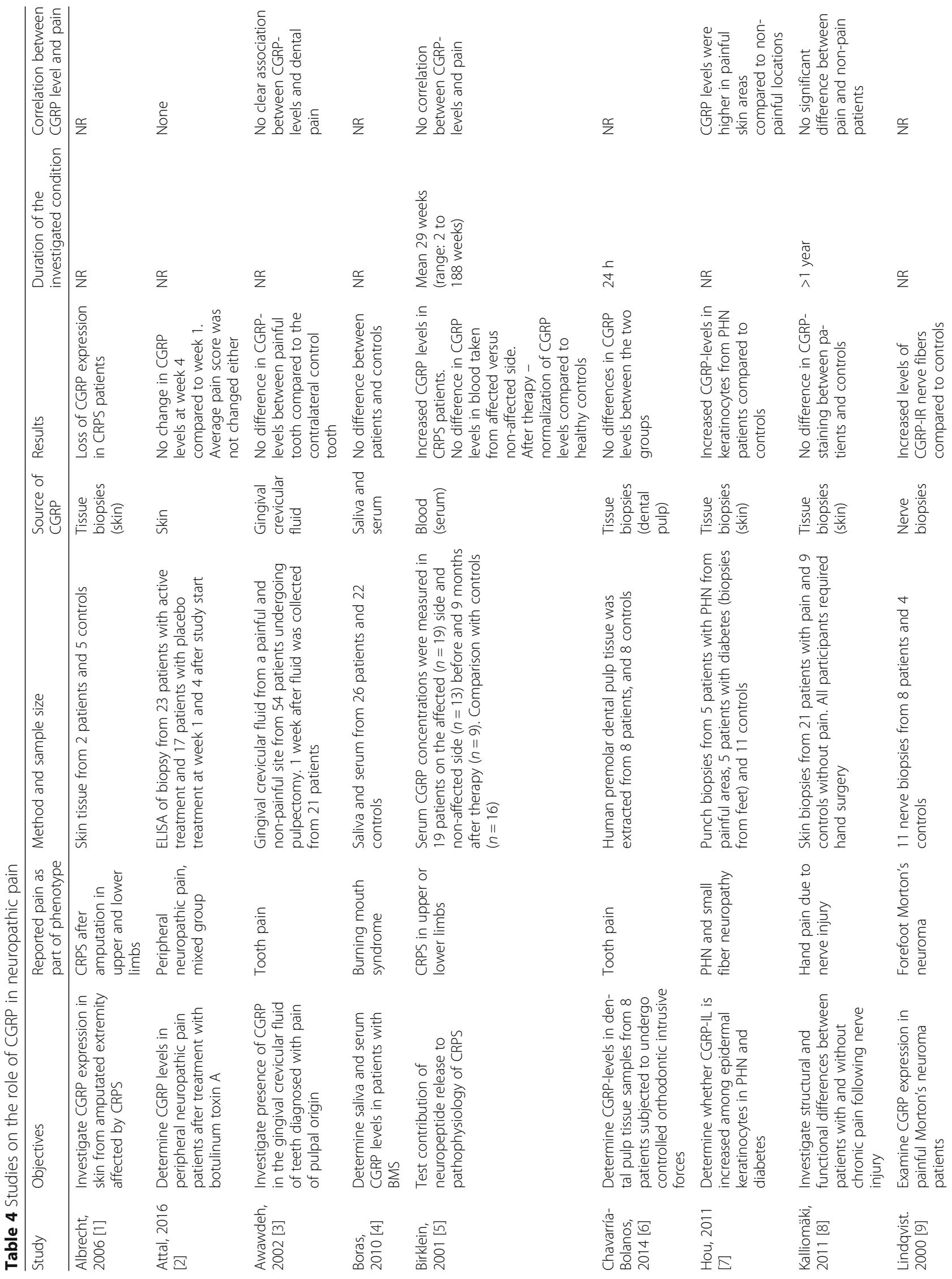




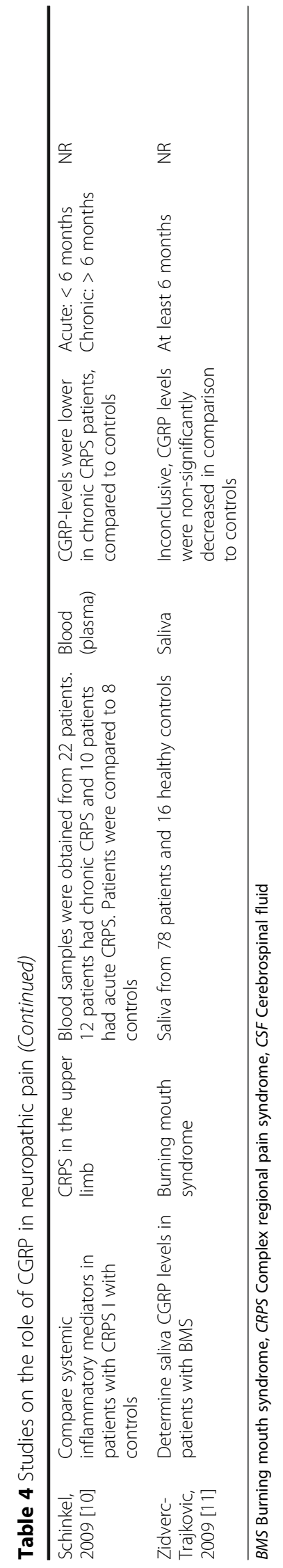


amputated limbs in CRPS patients showed loss of CGRP expression in two patients compared with skin biopsies from five controls. Correlation between pain measures and CGRP levels was not tested [57]. In post-herpetic neuralgia, increased CGRP expression in the affected skin compared with skin from a contralateral side in the same patient was reported by using immunofluorescence analyses of skin biopsies [58]. In one study using immunofluorescence of skin biopsies [59] no difference in CGRP expression was found between patients with chronic pain due to nerve injury after hand surgery and controls. The immunohistochemistry of peripheral nerve biopsies harvested from patients with Morton's neuroma, which results in neuropathic pain, showed increased amount of CGRP in patients compared with controls [60].

Four studies reported on CGRP radioimmunoassay: 1) gingival crevicular fluid in unilateral tooth pain patients [61] 2) saliva from burning mouth syndrome patients $[62,63]$, and 3) pulp biopsy in patients undergoing orthodontic intrusion [64]. None of the studies reported alteration in CGRP expressions in painful sides when compared with the non-painful side [61] or with controls [62, 64].

Attal et al. [65] investigated 152 patients with peripheral neuropathic pain of whom 68 were treated with botulinum toxin A and 66 received placebo. CGRP was analyzed in skin biopsies using ELISA at week 1 and 4 in 23 patients who received botulinum toxin $\mathrm{A}$ and in 17 patients who received placebo. No difference between groups was found [65].

\section{CGRP antagonists and antibodies and clinical trials}

We did not identify any clinical trials on CGRP antagonists and antibodies for the treatment of non-headache pain by searching PubMed and Embase. Search on ClinicalTrial.gov for current CGRP antagonists and antibodies for the treatment of non-headache pain only yielded three studies.

The acute effect of PF-04427429 anti-CGRP monoclonal antibody, on attenuation of flare response after capsaicin challenge, used to induce experimental human pain, was studied in a double blind, randomized, placebo-controlled, third-party open, modified crossover study in male healthy volunteers and using EMLA ${ }^{\circ}$ cream as positive control [66]. However, primary outcome measure of the study was mean blood perfusion induced by capsaicin challenge (results not reported on ClinicalTrials.gov) and no pain perception measures were studied.

A phase 2 randomized, double-blind, placebo and active-controlled trial in patients with mild to moderate osteoarthritis knee pain failed to demonstrate efficacy of LY2951742, monoclonal antibody to CGRP [67]. The study was terminated. A total of 266 patients were randomized to 1 of 6 treatment arms: LY2951742 $5 \mathrm{mg}$, $50 \mathrm{mg}, 120 \mathrm{mg}$, or $300 \mathrm{mg}$, celecoxib $200 \mathrm{mg}$, or placebo. Using a Bayesian dose-response longitudinal model, response rates to all four LY2951742 treatment arms were not different from placebo while celecoxib met criteria for a positive study [68].

An ongoing study on remote ischemic conditioning in patients with ulcerative colitis a condition associated with abdominal pain and diarrhea is still in a recruiting phase [69]. Investigators plan to study changes of serum and mucosal CGRP levels (secondary endpoints) in patients with ischemic colitis after remote ischemic conditioning, a repeated brief and non-harmful suppression of blood circulation induced by placing a blood pressure cuff around the right or left arm.

\section{Discussion}

\section{Summary of findings}

The present review revealed the association between measured CGRP levels and somatic visceral, neuropathic and inflammatory pain. We found that in somatic pain conditions in particular, CGRP levels correlated with pain. Increased CGRP levels were reported in plasma, synovial and cerebrospinal fluid, tissue biopsies in individuals with degenerative disc disease, osteoarthritis and TMJ-pain. Furthermore, CGRP was elevated in acute pain conditions and pain after exercise.

In total 13 out of 20 studies on somatic pain increased levels of CGRP were reported. Five studies showed no difference or had no control group. Four out of eight studies investigated CGRP in experimental models of inflammatory pain. The remaining four studies reported elevated CGRP levels in patients with pain caused by scars and pruritus. There was no consensus regarding correlation between neuropathic pain and CGRP levels. Six out of eleven studies showed no difference in CGRP levels, three studies reported a positive correlation, and two studies reported a negative correlation between neuropathic pain and CGRP levels. In visceral pain conditions a correlation between gynecological pain and high CGRP levels were found in tissue biopsies and peritoneal fluid. However, only two studies used a control group or control conditions.

Thirty out of fifty studies (60\%) included controls and suggested an association between CGRP levels and the respective pain condition. Twenty-six (52\%) studies reported a positive association whereas four studies $(8 \%)$ reported decreased CGRP levels. Studies reporting positive association investigated blood (10 studies), skin (5 studies), synovial tissue/fluid (5 studies), and other affected tissues (6 studies). Collectively, these studies showed a positive correlation between high CGRP levels and somatic pain conditions, especially osteoarthritis, acute muscular pain and chronic joint/muscular pain. 
These findings raise two important questions: what is the role of CGRP in the transmission of nociceptive signals and whether CGRP causes or modulates pain?

\section{CGRP and pathophysiology of pain}

CGRP is widely distributed in the peripheral and central nervous system [70, 71] and CGRP receptors are expressed in pain pathways [72-76]. CGRP-like immunoreactivity (CGRP-LI) is found in $40-50 \%$ of dorsal root ganglia (DRG) neurons [77]. CGRP-LI was found C-fiber (46\%), delta-fiber (33\%), and A-alpha/beta fiber (17\%) neurons [77]. Moreover, CGRP is usually colocalized with other neuropeptides, including substance $P$ [78] and neurokinins [79] in DRG neurons. Peripheral CGRP-LI fibers terminate in lamina I, III and V of spinal cord [80] and CGRP-containing DRG neurons innervate joints [81]. Thus, CGRP and its receptors are widely distributed in peripheral and central pain pathways.

In animals CGRP can be released from peripheral and central nerve endings upon noxious pain mechanical stimulation of the skin [82-85]. In rats, the major part of circulating CGRP is released from perivascular nerve terminals $[86,87]$. Acute and chronic nociception leads to altered release of CGRP from sensory nerve endings and central terminals into the dorsal horn of the spinal cord [88-91]. In rats, CGRP applied spinally causes facilitation of central excitability and central sensitization $[92,93]$. Kessler et al. [94] demonstrated reduced mechanical allodynia in an animal model of OA following administration of an intrathecal CGRP receptor antagonist [94]. Animal in vitro studies reported direct activation of nociceptors by CGRP [95, 96]. CGRP injected into mouse hind paw skin produced mechanical allodynia [97]. In humans, however, a direct activation of nociceptive fibers is unlikely. CGRP injected intradermally or intramuscularly did not produce pain [98].

CGRP is also found in free nerve endings in skin and synovium) and perivascular afferents in different structures in both humans and animals [99-101]. The release of CGRP from these fibers causes vasodilation suggesting a role in neurogenic inflammation [98, 101, 102]. The question is whether CGRP exerts either pro- or antiinflammatory/nociceptive effects. It is possible that CGRP release reflects the response of the nocifensor system to injury and inflammation to evoke protective vasodilatation. Deficiency of alpha CGRP ( $\alpha$ CGRP knockout mice) was associated with enhanced inflammatory responses in the hippocampus and hypothalamus and reduced the survival rate compared to wild-type mice in septic shock condition [103]. However, $\alpha$ CGRP knockout mice displayed lower pain sensitivity to heat stimulation faster accumulation of c-Fos compared to wild-type animals after incision and complete Freund's adjuvant injection [104]. In animals, sustained CGRP release may induce peripheral sensitization [105] likely due to release of inflammatory mediators (bradykinin, prostaglandins, etc.) from nerve endings and cells of immune system [106-108].

Inflammatory diseases of the joints tendons and discs may be associated with elevated levels of CGRP (Additional files 1 and 2: Tables S1 and S2). These data suggest that abnormal release of CGRP could be a marker of sensory afferent activation. Comparing CGRP changes in different tissue materials (i.e. blood, synovium, skin, CSF, ligament tissue, mucosa, etc.), it seems that elevated CGRP is more frequently found in blood, synovium and skin. Bullock et al. [109] suggested that CGRP release during joint degeneration in osteoarthritis might play an important role in the peripheral sensitization and proposed possible analgesic effect of CGRP antagonists in this condition. CGRP stimulates proliferation and migration of human endothelial cells [110], causing angiogenesis with the co-localized CGRPcontaining perivascular nerve fibers. Intra-articular growth of CGRP-containing perivascular nociceptors have been reported in patients with osteoarthritis. It has further been shown that nociceptive nerve fibers innervating joints are sensitized in these patients [111] contributing to the experience of pain. Immunohistochemistry of forearm skin biopsies in patients with congenital insensitivity to pain (CIP) showed reduced amount of CGRP compared to controls [112]. Thus, measurement of CGRP may be regarded a marker of sensory afferent activation in the respective tissue during a pain condition [113]. This indicates that CGRP not only contributes to proliferation of CGRP-containing nociceptors, but could sensitize these nociceptors via neurogenic inflammation in humans. Whether CGRP causes pain per se can be examined by application of exogenous CGRP. Interestingly, dose-dependent angiogenesis after intraarticular CGRP injection in the rat knee can be blocked by the CGRP receptor antagonist, BIBN4096BS [114]. One way of exploring this hypothesis would be to study CGRP levels in humans after exposure to painful stimuli. In healthy volunteers, intradermal capsaicin injections produced a steady increase of CGRP levels in the first sampling period, but failed to reach significance in the second session [45]. The latter could be explained by capsaicin-induced desensitization of neuropeptide release from primary afferents [115]. Another study demonstrated that capsaicin-induced vasodilation in the human skin was mainly mediated by CGRP and not by other substances with vasodilator properties including prostaglandins, nitric oxide, or substance P [116]. Only few studies have investigated the effect of CGRP antagonist after intradermal capsaicin injections [66, 117]. Chi-Chung Li et al. [117] reported that CGRP antagonist MK-3207 inhibited capsaicin-induced vasodilation in skin. Sinclair et al. [118] demonstrated reduced increase 
in dermal blood flow after topical capsaicin application in the forearm of healthy volunteers who were pretreated with CGRP antagonist (telcagepant). The degree of inhibition in capsaicin-induced dermal blood flow was shown to be increased with higher LY2951742, CGRP monoclonal antibody, plasma concentrations suggesting dose-response relationship [119].

While increased CGRP levels in the affected tissue and synovial material indicate ingrowth of pain sensitive nerve fibers in the tissue it is unclear why CGRP level increases in blood and skin. CGRP is synthesized in central and peripheral neurons [120]. Two studies investigated CGRP levels in the cerebrospinal fluid during pain and found 1) no difference in cancer pain patients compared to controls [35], and 2) low CGRP levels in osteoarthrosis patients [25]. In contrast, biochemical studies in osteoarthrosis patients reported a positive association between pain and CGRP levels in blood [17, 18], synovial material [20-22], and skin [19]. Dermal electrical current stimulation in humans caused increased CGRP in blood [48]. However, a recent study randomized, double-blind, placebo and active-controlled study in patients with osteoarthritis knee pain did not demonstrate efficacy of LY2951742, monoclonal antibody to CGRP against placebo and the trial was terminated [68]. However, the study was only done in patients with mild and moderate symptoms. It is possible that patients with severe osteoarthritis involving other joints may respond differently. Other factors that may confound the results include the long duration of the disease (not reported in abstract), which can indicate presence of central sensitization and level of activity of patients that may worsen symptoms including pain. No studies to date have investigated the efficacy of monoclonal antibodies against CGRP receptor in patients with osteoarthritis knee pain.

Further studies addressing these issues are warranted.

\section{Conclusions}

The present review suggests that CGRP may play a role in pain transmission in somatic pain conditions such as joint and muscular chronic pain. CGRP might have a pro-inflammatory role in peripheral nervous system by leading to release of pro-nociceptive substances and by facilitating central nociceptive transmission and contributing to central sensitization. However, the exact mechanisms and involvement of CGRP in nociceptive processing are not fully clarified. Understanding these mechanisms may lead to the potential development of new pharmacotherapies targeting CGRP and its receptors. Efficacy and safety of the CGRP antagonists and antibodies has already been established in migraine and this paves the way for more clinical trials in nonheadache pain conditions.

\section{Additional files}

Additional file 1: Table S1. Brief overview of used methods and the association between pain and CGRP in each category. (DOC $72 \mathrm{~kb}$ )

Additional file 2: Table S2. Brief overview of used methods and the association between pain and CGRP in the musculoskeletal category. (DOC 37 kb)

\section{Abbreviations}

CGRP: Calcitonin gene-related peptide; CGRP-LI: Calcitonin gene-related peptide - like immunoreactivity; CIP: Congenital insensitivity to pain; CNS: Central nervous system; CRPS: Complex regional pain syndrome; DRG: Dorsal root ganglia; TMJ: Temporomandibular joint

\section{Funding}

We thank the Lundbeck Foundation (R155-2014-171).

\section{Authors' contributions}

WSS conducted the literature search. All authors contributed with data interpretation, drafting and revision of the manuscript. All authors read and approved the final manuscript.

\section{Competing interests}

WSS, SA, and FMA report no conflicts of interest in relation to this paper. PJG reports personal fees from Amgen, during the conduct of the study; PJG also reports grants and personal fees from Allergan and eNeura, and personal fees from Autonomic Technologies, Bristol-Myers Squibb, Alder Biopharmaceuticals, Pfizer, Impax, Dr Reddy's Laboratories, Zosano, CoLucid, Eli Lilly, Medtronic, Avanir, Gore, Heptares, NuPathe, and Teva Pharmaceuticals. MA reports personal fees from Alder Biopharmaceuticals, Allergan, Amgen, Autonomic Technologies (ATI), Eli Lilly and Teva Pharmaceuticals, outside the submitted work; MA is also a principal investigator (PI) for Amgen trials 20120178, 20120295, 20130255, and 20120297, and GM-11 gammaCore-R trial.

\section{Author details}

${ }^{1}$ Danish Headache Center, Department of Neurology, Rigshospitalet Glostrup, University of Copenhagen, Copenhagen, Denmark. ${ }^{2}$ Department of Neurology, NYU Lutheran Headache Center, New York University School of Medicine, NYU Langone Medical Center, New York, NY, USA. ${ }^{3}$ Basic \& Clinical Neuroscience, and NIHR-Wellcome Trust King's Clinical Research Facility, King's College London, London, UK.

Received: 7 January 2017 Accepted: 28 February 2017

Published online: 16 March 2017

\section{References}

1. Julius D, Basbaum Al (2001) Molecular mechanisms of nociception. Nature 413:203-210

2. Baliki MN, Apkarian AV (2015) Nociception, pain, negative moods, and behavior selection. Neuron 87:474-491

3. Breivik H, Collett B, Ventafridda V, Cohen R, Gallacher D (2006) Survey of chronic pain in Europe: prevalence, impact on daily life, and treatment. Eur J Pain 10:287-333

4. McNamee P, Mendolia S (2014) The effect of chronic pain on life satisfaction: evidence from Australian data. Soc Sci Med 121:65-73.

5. Takai Y, Yamamoto-Mitani N, Abe Y, Suzuki M (2015) Literature review of pain management for people with chronic pain. Jpn J Nurs Sci 12: 167-183

6. Haut SR, Bigal ME, Lipton RB (2006) Chronic disorders with episodic manifestations: focus on epilepsy and migraine. Lancet Neurol 5:148-157

7. Schytz HW, Hargreaves R, Ashina M (2016) Challenges in developing drugs for primary headaches. Prog Neurobiol. doi:10.1016/j.pneurobio.2015.12.005 [Epub ahead of print]

8. Ho TW, Edvinsson L, Goadsby PJ (2010) CGRP and its receptors provide new insights into migraine pathophysiology. Nat Rev Neurol 6:573-582

9. Lassen LH, Haderslev PA, Jacobsen VB, Iversen HK, Sperling B (2002) CGRP may play a causative role in migraine. Cephalalgia 22:54-61

10. Sun H, Dodick DW, Silberstein S, Goadsby PJ, Reuter U, Ashina M, Saper J, Cady R, Chon Y, Dietrich J, Lenz R (2016) Safety and efficacy of AMG 334 for 
prevention of episodic migraine: A randomised, double-blind, placebocontrolled, phase 2 trial. Lancet Neurol 15:382-390

11. Bigal ME, Dodick DW, Rapoport AM, Silberstein SD, Ma Y, Yang R, Loupe PS, Burstein R, Newman LC, Lipton RB (2015) Safety, tolerability, and efficacy of TEV-48125 for preventive treatment of high-frequency episodic migraine: A multicentre, randomised, double-blind, placebo-controlled, phase $2 \mathrm{~b}$ study. Lancet Neurol 14:1081-1090

12. Dodick DW, Goadsby PJ, Silberstein SD, Lipton RB, Olesen J, Ashina M, Wilks K, Kudrow D, Kroll R, Kohrman B, Bargar R, Hirman J, Smith J, ALD403 study investigators (2014) Safety and efficacy of ALD403, an antibody to calcitonin gene-related peptide, for the prevention of frequent episodic migraine: $\mathrm{A}$ randomised, double-blind, placebo-controlled, exploratory phase 2 trial. Lancet Neurol 13:1100-1107

13. Amara SG, Jonas V, Rosenfeld MG, Ong ES, Evans RM (1982) Alternative RNA processing in calcitonin gene expression generates mRNAs encoding different polypeptide products. Nature 298:240-244

14. Brain SD, Cambridge H (1996) Calcitonin gene-related peptide: vasoactive effects and potential therapeutic role. Gen Pharmacol 27:607-611

15. Sexton PM (1991) Central nervous system binding sites for calcitonin and calcitonin gene-related peptide. Mol Neurobiol 5:251-273

16. Vécsei L, Szok D, Csáti A, Tajti J (2015) CGRP antagonists and antibodies for the treatment of migraine. Expert Opin Investig Drugs 24:31-41

17. Dong T, Chang H, Zhang F, Chen W, Zhu Y, Wu T, Zhang Y (2015) Calcitonin gene-related peptide can be selected as a predictive biomarker on progression and prognosis of knee osteoarthritis. Int Orthop 39:1237-1243

18. Lin WC, Yeh CH, Chien LC, Morone NE, Glick RM, Albers KM (2015) The antiinflammatory actions of auricular point acupressure for chronic Low back pain. Evid Based Complement Alternat Med. doi:10.1155/2015/103570., Epub 2015 Jun 11

19. Carlsson CP, Sundler F, Wallengren J (2006) Cutaneous innervation before and after one treatment period of acupuncture. Br J Dermatol 155:970-6

20. Saxler G, Löer F, Skumavc M, Pförtner J, Hanesch U (2007) Localization of SP- and CGRP-immunopositive nerve fibers in the hip joint of patients with painful osteoarthritis and of patients with painless failed total hip arthroplasties. Eur J Pain 11:67-74

21. Wang H, Zhang X, He JY, Zheng XF, Li D, Li Z, Zhu JF, Shen C, Cai GQ, Chen XD (2015) Increasing expression of substance $P$ and calcitonin gene-related peptide in synovial tissue and fluid contribute to the progress of arthritis in developmental dysplasia of the hip. Arthritis Res Ther 17:4

22. Takeshita M, Nakamura J, Ohtori S, Inoue G, Orita S, Miyagi M, Ishikawa T, Takahashi K (2012) Sensory innervation and inflammatory cytokines in hypertrophic synovia associated with pain transmission in osteoarthritis of the hip: a case-control study. Rheumatology (Oxford) 51:1790-5

23. Sato J, Segami N, Kaneyama K, Yoshimura H, Fujimura K, Yoshitake Y (2004) Relationship of calcitonin gene-related peptide in synovial tissues and temporomandibular joint pain in humans. Oral Surg Oral Med Oral Pathol Oral Radiol Endod 98:533-540

24. Ikeuchi M, Wang Q, Izumi M, Tani T (2012) Nociceptive sensory innervation of the posterior cruciate ligament in osteoarthritic knees. Arch Orthop Trauma Surg 132:891-895

25. Lindh C, Liu Z, Welin M, Ordeberg G, Nyberg F (1999) Low calcitonin generelated, peptide-like immunoreactivity in cerebrospinal fluid from chronic pain patients. Neuropeptides 33:517-521

26. Brown MF, Hukkanen MV, McCarthy ID, Redfern DR, Batten JJ, Crock HV, Hughes SP, Polak JM (1997) Sensory and sympathetic innervation of the vertebral endplate in patients with degenerative disc disease. J Bone Joint Surg (Br) 79:147-153

27. Ozawa T, Ohtori S, Inoue G, Aoki Y, Moriya H, Takahashi K (2006) The degenerated lumbar intervertebral disc is innervated primarily by peptidecontaining sensory nerve fibers in humans. Spine (Phila Pa 1976) 31:2418-2422

28. Alpar EK, Onuoha G, Killampalli W, Waters R (2002) Management of chronic pain in whiplash injury. J Bone Joint Surg (Br) 84:807-811

29. Takeuchi H, Kawaguchi S, Ohwada O, Kobayashi H, Hayakawa M, Takebayashi T, Troiqoe T, Sato N, Yamashita T (2007) Plasma neuropeptides in patients undergoing lumbar discectomy. Spine (Phila Pa 1976) 32:E79-84

30. Onuoha GN, Alpar EK (1999) Calcitonin gene-related peptide and other neuropeptides in the plasma of patients with soft tissue injury. Life Sci 65: 1351-1358

31. Larsson J, Ekblom A, Henriksson K, Lundeberg T, Theodorsson E (1991) Concentration of substance $P$, neurokinin $A$, calcitonin gene related peptide, neuropeptide $Y$ and vasoactive intestinal polypeptide in synovial fluid from knee joints in patients suffering from rheumatoid arthritis. Scand J Rheumatol 20:326-335

32. Bjur D, Alfredson H, Forsgren S (2005) The innervation pattern of the human Achilles tendon: studies of the normal and tendinosis tendon with markers for general and sensory innervation. Cell Tissue Res 320:201-206

33. Danielson P, Andersson G, Alfredson H, Forsgren S (2008) Marked sympathetic component in the perivascular innervation of the dorsal paratendinous tissue of the patellar tendon in arthroscopically treated tendinosis patients. Knee Surg Sports Traumatol Arthrosc 16:621-626

34. Sasaki K, Ohki G, Iba K, Kokai Y, Yamashita T, Wada T (2013) Innervation pattern at the undersurface of the extensor carpi radialis brevis tendon in recalcitrant tennis elbow. J Orthop Sci 18:528-535

35. Samuelsson H, Ekman R, Hedner T (1993) CSF neuropeptides in cancer pain: effects of spinal opioid therapy. Acta Anaesthesiol Scand 37:502-508

36. Jonhagen S, Ackermann P, Saartok T, Renstrom PA (2006) Calcitonin gene related peptide and neuropeptide $Y$ in skeletal muscle after eccentric exercise: A microdialysis study. Br J Sports Med 40:264-267

37. Barcena de Arellano ML, Arnold J, Vercellino GF, Chiantera V, Ebert AD, Schneider A, Mechsner S (2011) Influence of nerve growth factor in endometriosis-associated symptoms. Reprod Sci 18:1202-1210

38. Tokushige N, Markham R, Russell P, Fraser IS (2006) Nerve fibres in peritoneal endometriosis. Hum Reprod 21:3001-3007

39. Tokushige N, Markham R, Russell P, Fraser IS (2007) Different types of small nerve fibers in eutopic endometrium and myometrium in women with endometriosis. Fertil Steril 88:795-803

40. Tympanidis $P$, Terenghi $G$, Dowd $P$ (2003) Increased innervation of the vulval vestibule in patients with vulvodynia. Br J Dermatol 148:1021-1027

41. Yoshida N, Kuroda M, Suzuki T, Kamada K, Uchiyama K, Handa O, Takagi T, Yoshikawa T, Kuramoto H (2013) Role of nociceptors/neuropeptides in the pathogenesis of visceral hypersensitivity of nonerosive reflux disease. Dig Dis Sci 58:2237-2243

42. Mönnikes $H$, van der Voort IR, Wollenberg B, Heymann-Monnikes I, Tebbe JJ, Alt W, Arnold R, Klapp BF, Wiedenmann B, McGregor GP (2005) Gastric perception thresholds are low and sensory neuropeptide levels high in helicobacter pylori-positive functional dyspepsia. Digestion 71:111-123

43. Buchler M, Weihe E, Friess $H$, Malfertheiner $P$, Bockman E, Müller S, Nohr D, Beger HG (1992) Changes in peptidergic innervation in chronic pancreatitis. Pancreas 7:183-192

44. Währborg P, Eliasson T, Edvardsson N, Ekman R, Mannheimer C, Hedner T (1999) Acute ischemic chest pain is not associated with increased calcitonin gene-related peptide (CGRP) levels in peripheral plasma nor in the coronary circulation. Scand Cardiovasc J 33:295-299

45. Geber C, Fondel R, Krämer HH, Rolke R, Treede RD, Sommer C, Birklein F (2007) Psychophysics, flare, and neurosecretory function in human pain models: capsaicin versus electrically evoked pain. J Pain 8:503-514

46. Schmelz M, Luz O, Averbeck B, Bickel A (1997) Plasma extravasation and neuropeptide release in human skin as measured by intradermal microdialysis. Neurosci Lett 230:117-120

47. Simone DA, Nolano M, Johnson T, Wendelschafer-Crabb G, Kennedy WR (1998) Intradermal injection of capsaicin in humans produces degeneration and subsequent reinnervation of epidermal nerve fibers: Correlation with sensory function. J Neurosci 18:8947-8959

48. Krämer HH, Schmidt K, Leis S, Schmelz M, Sommer C, Birklein F (2005) Inhibition of neutral endopeptidase (NEP) facilitates neurogenic inflammation. Exp Neurol 195:179-184

49. Couture R, Regoli D (1981) Inactivation of substance P and its C-terminal fragments in rat plasma and its inhibition by Captopril. Can J Physiol Pharmacol 59:621-625

50. Hamed K, Giles N, Anderson J, Phillips JK, Dawson LF, Drummond P, Wallace H, Wood FM, Rea SM, Fear MW (2011) Changes in cutaneous innervation in patients with chronic pain after burns. Burns 37:631-637

51. Kwak IS, Choi YH, Jang YC, Lee YK (2014) Immunohistochemical analysis of neuropeptides (protein gene product 9.5, substance $P$ and calcitonin generelated peptide) in hypertrophic burn scar with pain and itching. Burns 40:1661-1667

52. Onuoha GN, Alpar EK (2001) Levels of vasodilators (SP, CGRP) and vasoconstrictor (NPY) peptides in early human burns. Eur J Clin Invest 31:253-257

53. Salomon J, Baran E (2008) The role of selected neuropeptides in pathogenesis of atopic dermatitis. J Eur Acad Dermatol Venereol 22:223-228 
54. Ringkamp M, Schepers RJ, Shimada SG, Johanek LM, Hartke TV, Borzan J, Shim B, LaMotte RH, Meyer RA (2011) A role for nociceptive, myelinated nerve fibers in itch sensation. J Neurosci 31:14841-14849

55. Birklein F, Schmelz M, Schifter S, Weber M (2001) The important role of neuropeptides in complex regional pain syndrome. Neurology $57: 2179-2184$

56. Schinkel C, Scherens A, Köller M, Roellecke G, Muhr G, Maier C (2009) Systemic inflammatory mediators in post-traumatic complex regional pain syndrome (CRPS I) - longitudinal investigations and differences to control groups. Eur J Med Res 14:130-135

57. Albrecht PJ, Hines S, Eisenberg E, Pud D, Finlay DR, Connolly MK, Paré M, Davar G, Rice FL (2006) Pathologic alterations of cutaneous innervation and vasculature in affected limbs from patients with complex regional pain syndrome. Pain 120:244-266

58. Hou Q, Barr T, Gee L, Vickers J, Wymer J, Borsani E, Rodella L, Getsios S, Burdo T, Eisenberg E, Guha U, Lavker R, Kessler J, Chittur S, Fiorino D, Rice F, Albrecht $P$ (2011) Keratinocyte expression of calcitonin gene-related peptide $\beta$ : implications for neuropathic and inflammatory pain mechanisms. Pain 152:2036-2051

59. Kalliomäki M, Kieseritzky JV, Schmidt R, Hägglöf B, Karlsten R, Sjögren N, Albrecht P, Gee L, Rice F, Wiig M, Schmelz M, Gordh T (2011) Structural and functional differences between neuropathy with and without pain? Exp Neurol 231:199-206

60. Lindqvist A, Rivero-Melian C, Turan I, Fried K (2000) Neuropeptide- and tyrosine hydroxylase-immunoreactive nerve fibers in painful Morton's neuromas. Muscle Nerve 23:1214-1218

61. Awawdeh LA, Lundy FT, Linden GJ, Shaw KJG, Lamey PJ (2002) Quantitative analysis of substance $P$, neurokinin $A$ and calcitonin gene-related peptide in gingival crevicular fluid associated with painful human teeth. Eur J Oral Sci 110 185-191

62. Zidverc-Trajkovic J, Stanimirovic D, Obrenovic R, Tajti J, Vécsei K, Gardi J, Németh J, Mijajlovic M, Sternic N, Jankovic L (2009) Calcitonin gene-related peptide levels in saliva of patients with burning mouth syndrome. J Oral Pathol Med 38:29-33

63. Boras W, Savage NW, Brailo V, Lukac J, Lukac M, Alajbeg IZ (2010) Salivary and serum levels of substance $P$, neurokinin $A$ and calcitonin gene related peptide in burning mouth syndrome. Med Oral Patol Oral Cir Bucal 15: e427-431

64. Chavarría-Bolaños D, Martinez-Zumaran A, Lombana N, Flores-Reyes H, Pozos-Guillen A (2014) Expression of substance $P$, calcitonin gene-related peptide, $\beta$-endorphin and methionine-enkephalin in human dental pulp tissue after orthodontic intrusion A pilot study. Angle Orthod 84:521-526

65. Attal N, de Andrade DC, Adam F, Ranoux D, Teixeira MJ, Galhardoni R, Raicher I, Üceyler N, Sommer C, Bouhassira D (2016) Safety and efficacy of repeated injections of botulinum toxin $A$ in peripheral neuropathic pain (BOTNEP): A randomised, double-blind, placebo-controlled trial. Lancet Neurol 15:555-565

66. Pfizer. Acute Response Capsaicin Flare Study. In ClinicalTrials.gov [Internet] Bethesda (MD): National Library of Medicine (US). 2000-[cited 2016 May 31] Available from: https://clinicaltrials.gov/ct2/show/NCT01147432.

67. Eli Lilly and Company. A Study of LY2951742 in Participants With Mild to Moderate Osteoarthritis Knee Pain. In ClinicalTrials.gov [Internet]. Bethesda (MD): National Library of Medicine (US). 2000-[cited 2016 May 31]. Available from: https://clinicaltrials.gov/ct2/show/NCT02192190.

68. Jin Y, Smith C, Monteith D, Brown R, Camporeale A, McNearney T, Deeg M, Raddad E, de la Pena A, Kivitz A, Schnitzer T (2016) LY2951742, a monoclonal antibody against CGRP, failed to reduce signs and symptoms of knee osteoarthritis. Osteoarthritis Cartilage 24:S50

69. Odense University Hopsital. Remote Ischemic Conditioning in Patients With Ulcerative Colitis. In ClinictalTrials.gov [Internet]. Bethesda (MD): National Library of Medicine (US). 2000-[cited 2016 May 31]. Available from: https:// clinicaltrials.gov/ct2/show/NCT02445365.

70. Tajti J, Uddman R, Edvinsson L (2001) Neuropeptide localization in the 'migraine generator' region of the human brainstem. Cephalalgia 21:96-101

71. van Rossum D, Hanisch UK, Quirion R (1997) Neuroanatomical localization, pharmacological characterization and functions of CGRP, related peptides and their receptors. Neurosci Biobehav Rev 21:649-678

72. Chakravarty P, Suthar TP, Coppock HA, Nicholl CG, Bloom SR, Legon S, Smith DM (2000) CGRP and adrenomedullin binding correlates with transcript levels for calcitonin receptor-like receptor (CRLR) and receptor activity modifying proteins (RAMPs) in rat tissues. BrJ Pharmacol 130:189-195
73. Ma W, Chabot JG, Powell KJ, Jhamandas K, Dickerson IM, Quirion R (2003) Localization and modulation of calcitonin gene-related peptide-receptor component protein-immunoreactive cells in the rat central and peripheral nervous systems. Neuroscience 120:677-694

74. Cottrell GS, Alemi F, Kirkland JG, Grady EF, Corvera CT, Bhargava A (2012) Localization of calcitonin receptor-like receptor (CLR) and receptor activitymodifying protein 1 (RAMP1) in human gastrointestinal tract. Peptides 35: 202-211

75. Cottrell GS, Roosterman D, Marvizon JC, Song B, Wick E, Pikios S, Wong H, Berthelier C, Tang Y, Sternini C, Bunnett NW, Grady EF (2005) Localization of calcitonin receptor-like receptor and receptor activity modifying protein 1 in enteric neurons, dorsal root ganglia, and the spinal cord of the rat. J Comp Neurol 490:239-255

76. Pokabla MJ, Dickerson IM, Papka RE (2002) Calcitonin gene-related peptidereceptor component protein expression in the uterine cervix, lumbosacral spinal cord, and dorsal root ganglia. Peptides 23:507-514

77. McCarthy PW, Lawson SN (1990) Cell type and conduction velocity of rat primary sensory neurons with calcitonin gene-related peptide-like immunoreactivity. Neuroscience 34:623-632

78. Belanger S, Ma W, Chabot JG, Quirion R (2002) Expression of calcitonin gene-related peptide, substance $P$ and protein kinase $C$ in cultured dorsal root ganglion neurons following chronic exposure to mu, delta and kappa opiates. Neuroscience 115:441-453

79. Yang YL, Yao KH, Li ZW (2003) Similarities of SP-, NKA- and NKB-induced currents in rat dorsal root ganglion neurons. Brain Res 991:18-25

80. Gibson SJ, Polak JM, Bloom SR, Sabate IM, Mulderry PM, Ghatei MA, McGregor GP, Morrison JF, Kelly JS, Evans RM (1984) Calcitonin gene-related peptide immunoreactivity in the spinal cord of man and of eight other species. J Neurosci 4:3101-3111

81. Fernihough J, Gentry C, Bevan S, Winter J (2005) Regulation of calcitonin gene-related peptide and TRPV1 in a rat model of osteoarthritis. Neurosci Lett 388:75-80

82. Morion CR, Hutchison WD (1989) Release of sensory neuropeptides in the spinal cord: Studies with calcitonin gene-related peptide and galanin. Neuroscience 31:807-815

83. Sauer SK, Bove GM, Averbeck B, Reeh PW (1999) Rat peripheral nerve components release calcitonin gene-related peptide and prostaglandin E2 in response to noxious stimuli: Evidence that nervi nervorum are nociceptors. Neuroscience 92:319-325

84. Schaible HG, Freudenberger U, Neugebauer V, Stiller RU (1994) Intraspinal release of immunoreactive calcitonin gene-related peptide during development of inflammation in the joint in vivo-a study with antibody microprobes in cat and rat. Neuroscience 62:1293-1305

85. Ogbonna AC, Clark AK, Gentry C, Hobbs C, Malcangio M (2013) Pain-like behaviour and spinal changes in the monosodium iodoacetate model of osteoarthritis in C57BI/6 mice. Eur J Pain 17:514-526

86. Wimalawansa SJ, Maclntyre I (1988) Heterogeneity of plasma calcitonin gene-related peptide: partial characterisation of immunoreactive forms. Peptides 9:407-410

87. Zaidi M, Bevis PJ, Abeyasekera G, Girgis SI, Wimalawansa SJ, Morris HR, Maclntyre I (1986) The origin of circulating calcitonin gene-related peptide in the rat. J Endocrinol 110:185-190

88. Buzzi MG, Carter WB, Shimizu T, Health H 3rd, Moskowitz MA (1991) Dihydroergotamine and sumatriptan attenuate levels of CGRP in plasma in rat superior sagittal sinus during electrical stimulation of the trigeminal ganglion. Neuropharmacology 30:1193-1200

89. Levine JD, Fields HL, Basbaum Al (1993) Peptides and the primary afferent nociceptor. J Neurosci 13:2273-2286

90. Morton CR, Hutchison WD (1990) Morphine does not reduce the intraspinal release of calcitonin gene-related peptide in the cat. Neurosci Lett 117:319-324

91. Weihe E, Schäfer MK, Nohr D, Persson S (1994) Expression of neuropeptides, neuropeptide receptors and neuropeptide processing enzymes in spinal neurons and peripheral non-neural cells and plasticity in models of inflammatory pain. In: Hokfelt T, Schaible HG, Schmidt RF (eds) Neuropeptides, nociception and Pain. Chapman \& Hall, London

92. Leem JW, Gwak YS, Lee EH, Chung SS, YS K, Nam TS (2001) Effects of iontophoretically applied substance $\mathrm{P}$, calcitonin gene-related peptide on excitability of dorsal horn neurones in rats. Yonsei Med J 42:74-83

93. Sun RQ, Tu YJ, Lawand NB, Yan JY, Lin Q, Willis WD (2004) Calcitonin generelated peptide receptor activation produces PKA- and PKC-dependent 
mechanical hyperalgesia and central sensitization. J Neurophysiol 92:2859-2866

94. Kessler F, Habelt C, Averbeck B, Reeh PW, Kress M (1999) Heat-induced release of CGRP from isolated rat skin and effects of bradykinin and the protein kinase $C$ activator PMA. Pain 83:289-295

95. Segond von Banchet G, Pastor A, Biskup C, Schlegel C, Benndorf K, Schaible HG (2002) Localization of functional calcitonin gene-related peptide binding sites in a subpopulation of cultured dorsal root ganglion neurons. Neuroscience 110:131-145

96. Natura G, von Banchet GS, Schaible HG (2005) Calcitonin gene-related peptide enhances TTX-resistant sodium currents in cultured dorsal root ganglion neurons from adult rats. Pain 116:194-204

97. Shi X, Wang L, Li X, Sahbaie P, Kingery WS, Clark JD (2011) Neuropeptides contribute to peripheral nociceptive sensitization by regulating interleukin$1 \beta$ production in keratinocytes. Anesth Analg 113:175-183

98. Pedersen-Bjergaard U, Nielsen LB, Jensen $K$, Edvinsson L, Jansen I, Olesen J (1991) Calcitonin gene-related peptide, neurokinin A and substance $P$. Effects on Nociception and neurogenic inflammation in human skin and temporal muscle. Peptides 12:333-337

99. Pereira da Silva JA, Carmo-Fonseca M (1990) Peptide containing nerves in human synovium: Immunohistochemical evidence for decreased innervation in rheumatoid arthritis. J Rheumatol 17:1592-1599

100. Gibbins IL, Wattchow D, Coventry B (1987) Two immunohistochemically identified populations of calcitonin gene-related peptide (CGRP)immunoreactive axons in human skin. Brain Res 414:143-148

101. Fujimori A, Saito A, Kimura S, Watanabe T, Uchiyama Y, Kawasaki H, Goto K (1989) Neurogenic vasodilation and release of calcitonin gene-related peptide (CGRP) from perivascular nerves in the rat mesenteric artery. Biochem Biophys Res Commun 165:1391-1398

102. Uddman R, Edvinsson L, Ekblad E, Håkanson R, Sundler F (1986) Calcitonin gene-related peptide (CGRP): perivascular distribution and vasodilatory effects. Regul Pept 15:1-23

103. Lee JK, Jung JS, Park SH, Sim YB, Sub HW (2013) Deficiency of alphacalcitonin gene-related peptide induces inflammatory responses and lethality in sepsis. Cytokine 64:548-554

104. Ishida K, Kawamata T, Tanaka S, Shindo T, Kawamata M (2014) Calcitonin gene-related peptide is involved in inflammatory pain but not in postoperative pain. Anesthesiology 121:1068-1079

105. Nakamura-Craig M, Gill BK (1991) Effect of neurokinin A, substance P and calcitonin gene related peptide in peripheral hyperalgesia in the rat paw. Neurosci Lett 124:49-51

106. Schaible HG, Schmidt RF (1988) Excitation and sensitization of fine articular afferents from cat's knee joint by prostaglandin E2. J Physiol 403:91-104

107. Birrell GJ, McQueen DS, Iggo A, Coleman RA, Grubb BD (1991) PGI2-induced activation and sensitization of articular mechanonociceptors. Neurosci Lett 124:5-8

108. Wang H, Ehnert C, Brenner GJ, Woolf CJ (2006) Bradykinin and peripheral sensitization. Biol Chem 387:11-14

109. Bullock CM, Kelly S (2013) Calcitonin gene-related peptide receptor antagonists: beyond migraine pain-a possible analgesic strategy for osteoarthritis? Curr Pain Headache Rep 17:375

110. Haegerstrand A, Dalsgaard CJ, Jonzon B, Larsson O, Nilsson J (1990) Calcitonin gene-related peptide stimulates proliferation of human endothelial cells. Proc Natl Acad Sci U S A 87:3299-3303

111. Arendt-Nielsen L, Nie H, Laursen MB, Laursen BS, Madeleine P. Simonsen $\mathrm{OH}$, Graven-Nielsen T (2010) Sensitization in patients with painful knee osteoarthrosis. Pain 149:573-581

112. Axelsson HE, Minde JK, Sonesson A, Toolanen G, Högestätt ED, Zygmunt PM (2009) Transient receptor potential vanilloid 1, vanilloid 2 and melastatin 8 immunoreactive nerve fibers in human skin from individuals with and without Norrbottnian congenital insensitivity to pain. Neuroscience 162: 1322-1332

113. Sulaiman H, Gabella G, Davis MSc C, Se M, Boulos P, Laurent GJ, Herrick SE (2001) Presence and distribution of sensory nerve fibers in human peritoneal adhesions. Ann Surg 234:256-261

114. Mapp PI, McWilliams DF, Turley MJ, Hargin E, Walsh DA (2012) A role for the sensory neuropeptide calcitonin gene-related peptide in endothelial cell proliferation in vivo. Br J Pharmacol 166:1261-1271

115. Amann R (1990) Desensitization of capsaicin-evoked neuropeptide release-influence of $\mathrm{Ca} 2+$ and temperature. Naunyn Schmiedebergs Arch Pharmacol 342:671-676
116. Van der Schueren BJ1, Rogiers A, Vanmolkot FH, Van Hecken A, Depré M, Kane SA, De Lepeleire I, Sinclair SR, de Hoon JN (2008) Calcitonin generelated peptide8-37 antagonizes capsaicin-induced vasodilation in the skin: evaluation of a human in vivo pharmacodynamic model. J Pharmacol Exp Ther 325:248-255.

117. Li CC, Vermeersch S, Denney WS, Kennedy WP, Palcza J, Gipson A, Han TH, Blanchard R, De Lepeleire I, Depré M, Murphy MG, Van Dyck K, de Hoon JN (2015) Characterizing the PK/PD relationship for inhibition of capsaicininduced dermal vasodilatation by MK-3207, an oral calcitonin gene related peptide receptor antagonist. Br J Clin Pharmacol 79:831-837

118. Sinclair SR, Kane SA, Van der Schueren BJ, Xiao A, Willson KJ, Boyle J (2010) Inhibition of capsaicin-induced increase in dermal blood flow by the oral CGRP receptor antagonist, telcagepant (MK-0974). Br J Clin Pharmacol 69:15-22

119. Vermeersch S, Benschop RJ, Van Hecken A, Monteith D, Wroblewski VJ, Grayzel D, de Hoon J, Collins EC (2015) Translational Pharmacodynamics of Calcitonin Gene-Related Peptide Monoclonal Antibody LY2951742 in a Capsaicin-Induced Dermal Blood Flow Model. J Pharmacol Exp Ther 354:350-357

120. Rosenfeld MG, Mermod JJ, Amara SG, Swanson LW, Sawchenko PE, Rivier J, Vale WW, Evans RM (1983) Production of a novel neuropeptide encoded by calcitonin gene via tissue-specific RNA processing. Nature 304:129-135

\section{Submit your manuscript to a SpringerOpen ${ }^{\circ}$ journal and benefit from:}

- Convenient online submission

Rigorous peer review

- Immediate publication on acceptance

- Open access: articles freely available online

- High visibility within the field

- Retaining the copyright to your article

Submit your next manuscript at $\gg$ springeropen.com 